\title{
Long Noncoding RNA LINC00839 Promotes the Malignant Progression of Osteosarcoma by Competitively Binding to MicroRNA-454-3p and Consequently Increasing c-Met Expression [Retraction]
}

Zhang Y, Guo H, Ma L, Chen X, Chen G. Cancer Manag

Res. 2020;12:8975-8987.

The Editor and Publisher of Cancer Management and Research wish to retract the published article. Concerns were raised over alleged image duplication in Figure 5C with similar images from unrelated articles, specifically:

- Figure 5C panel HOS si-LINC00839+pcDNA3.1 appears to have been duplicated with similar images in Figure 1I panel MDA-MB-231 si-LINC00922 from Yue and Wang, 2020 (https://doi.org/10.2147/ CMAR.S267665) and Figure 4B panel agomir-483-
$3 p$ from Li et al, 2019 (https://doi.org/10.18632/ aging.102563).

The authors did not respond to our queries and the Editor determined the findings of the study were no longer valid and advised for the article to be retracted.

Our decision-making was informed by our policy on publishing ethics and integrity and the COPE guidelines on retraction.

The retracted article will remain online to maintain the scholarly record, but it will be digitally watermarked on each page as "Retracted".

\section{Publish your work in this journal}

Cancer Management and Research is an international, peer-reviewed open access journal focusing on cancer research and the optimal use of preventative and integrated treatment interventions to achieve improved outcomes, enhanced survival and quality of life for the cancer patient.
The manuscript management system is completely online and includes a very quick and fair peer-review system, which is all easy to use. Visit http://www.dovepress.com/testimonials.php to read real quotes from published authors. 